\title{
LUIS ANTONIO DE VILLENA, Imágenes en fuga de esplendor y tristeza, Madrid,
} Visor, 2016, 242 pp.

Imágenes en fuga de esplendor y triste$z a$ supone una actualización de la poesía de Luis Antonio de Villena y no es un libro más dentro de su ya extensa e intensa trayectoria, sino una cala, o profundización en un «ciclo» - por establecer algún tipo de taxonomía - que comenzó con La prosa del mundo (2007), continuó con Proyecto para excavar una villa romana en el páramo (2011), y que tiene ahora esta extraordinaria tercera entrega de la mano de las galerías inextricables e inaprensibles de internet, la realidad virtual y el mundo de la imagen, tan de ahora, tan en la retina. Además, podríamos subrayar que no se trata, en cualquier caso, de partes de un mismo volumen, sino que nos referimos a una particular discursividad que viene fraguándose desde décadas anteriores, decantándose y perfeccionándose, y que cada vez se plantea como una superación o vuelta de tuerca a un estilo muy personal. Así, la voz de Luis Antonio de Villena posee marcas que nos hablan de ciertos rasgos que la caracterizan a través de los años, y esparcidos en sus diferentes obras. Podría haberse titulado este libro «Imágenes en fuga de esplendor y belleza», pues la belleza (en toda su latitud, sin faltar los contrapuntos), como bien titulara el autor su obra poética completa, es una de las constantes a la hora de delimitar su obra. Pero la tristeza viene señalada por el tiempo ido, esa fuga de lo que ya nunca volverá. Un canto o elegía - canto elegiaco - a la juventud, la fuerza y la plenitud vital, no solo física, sino también anímica.

Estos rasgos villenianos podrían detectarse desde libros muy tempranos, pero centrándonos en este "ciclo», diríamos que hay una indiferenciación buscada entre la poesía y la prosa, que ha ido fraguándose en las últimas décadas. El propio autor, en su ya habitual «nota al final» a sus libros, suele facilitarnos algunas indicaciones de cómo se ha desarrollado este poemario, las fechas, o algún otro elemento útil para la hermeneusis o intencionalidad que suelen ser bastante interesantes:

«Me gusta mezclar altos y bajos niveles lingüísticos y buscar un poe- 
ma con versos largos y ritmos nuevos, que admitan los sonidos de quiebros y encabalgamientos y no sólo lo sonidos - rimas - de cada fin versal. No hay poesía sin sonoridad y pasión, pero la estricta métrica tradicional resulta abusada y monocorde, incluso sin rimas consonantes. Busco territorios nuevos en la sonoridad versicular, aunque sé que muchos no quieren permitirlo. Pero eso nada importa» (pp. 236-237).

Podríamos decirlo nosotros de otro modo pero no mejor, ya que este aspecto sonoro que el poeta resalta, nos parece muy destacado del conjunto de la escritura villeniana. $Y$ hablamos de escritura como un todo, una estructura en la que la prosa es un tejido donde se escancia la poesía, la frase adquiere una torsión que se adapta a la dicción, una manera de verter una prosodia - de amoldar - que se va derramando por las historias, las cláusulas de la respiración y los giros con las subsiguientes aclaraciones, los cortes y las continuaciones que son necesarios para ampliar, detallar o, en cualquier caso, resaltar algún elemento, sensación o idea que el autor quiere poner de relieve. Es sin duda este rasgo muy definidor de la particular manera de ritmar de Luis Antonio de Villena, y llama poderosamente la atención en el conjunto de su obra, también apreciable en artículos y relatos. Se pone en evidencia así la tesis de que un escritor no se divide en compartimentos estancos, sino que reparte su arte con estilo, a la manera grecolatina, y que este - el estilo - lo define hasta el punto que es el que le dicta a posteriori cómo enmarcar los géneros, y no al contrario. El estilo hace el género, por tanto. El estilo como lugar de llegada, nunca como espacio de partida. La escritura como resultado y no como manifiesto de intenciones.

Dicho esto, y basten estas breves palabras como acercamiento admirativo a las más de doscientas páginas de estas Imágenes en fuga de esplendor y tristeza, Luis Antonio de Villena se sumerge en un particular laberinto verbal e imaginístico que mezcla culturalismo y realismo a la vez. Torrencial su expresión, abre muchos canales, navega por extraños lugares, deriva hacia donde menos se espera, nos sorprende con personajes olvidados y excéntricos (véase, por ejemplo, Carolina Otero en «Dos fotos de revista», pp. 20-21)... Los textos son, como bien reza el título del libro, «imágenes» en su mayoría, y algunos vienen convenientemente ilustrados con una foto que representa bien al personaje del que se habla o bien algún bello muchacho. La voz verbal está guiada por un «fotógrafo», que pensamos - y no es mera suposición - que en muchas ocasiones «coincide» con el propio autor de los textos... «Bueno, bastarán unas fotos» (de «Esplendor lejano», p. 16), «Vendí muy bien las fotos» (de «El basurero», p. 28), o «No pudo haber foto» (en el inicio del poema siguiente, «Acoso escolar, p. 30). La miscelánea va desde recuerdos familiares y sentimentales, «Tío Mario» (pp. 40-41) o «Papá y mamá, 1955» (pp. 124-125), hasta historias de la vida crápula madrileña o de cualquier otro lugar del mundo, como 
en «Tino» (pp. 24-25). Y dice allí mismo: «Las nubes tapan la luna, la farlopa está cortada, la playa pertenece a un mal hotel y nosotros tampoco existimos» (p. 25). Con un particular énfasis en el mundo de la homosexualidad y, esta vez, de la pornografía («Pornografía», pp. 36-37, o «Jean Daniel Cadinot, pornógrafo», pp. 128-129), entre otros, y en general marginados por cualquier tipo de condición. O los retratos de personajes históricos, como «Pu Yi» (pp. 34-35), o «Felipe III, Hispaniarum Rex» (pp. 217-218), por citar solo algunos. Sin olvidar los retratos y homenajes a artistas, pintores, escritores, etc., que van trufando también estas Imágenes en fuga de esplendor y tristeza, no exentas de pasión y melancolía: «Edgar Lee Masters» (pp. 26-27), «Monsieur Gauguin» (pp. 42-43), «Luis Cernuda» (pp. 50-51), «Marcel» (pp. 187-188) o «Pasolini» (pp. 191-192)...

Nadie advirtió como tú, con clarividencia tanta, la peste que venía detrás, cómo el capitalismo vendía al humanismo y se desvanecía el mundo que fue nuestro, entre la muerte del pueblo y el triunfo de la avaricia y los innúmeros ladrones a los que ya maldijera Pound, el fascista lúcido. Homosexual, perverso, enemigo de la infame Democracia Cristiana - tan vil - buscador de los muchachos de las barriadas pobres, con la áspera y bendita belleza de la vida, hermosos y soeces, cómo no habrían de buscar tu fin quienes lo están deshaciendo todo? Atacabas a la Iglesia esclerótica, la rapiña de los ricos, la obtusez cretina de la partitocracia gélida [...] (ibíd.).

...entre otros, personajes e historias que llevan siempre a reflexiones sobre la miseria y la grandeza humanas, a la exaltación y a la decepción de nuestra condición, a su denuncia al fin y al cabo. De hecho, estas reflexiones vienen intercaladas en general en el conjunto de los textos, pero a veces se encarnan en un solo «texto», como en el magnífico «Poder, ambición» (pp. 38-39), donde a propósito de César y Antonio se establece una suerte de retrato diacrónico de la humanidad. Mucho podríamos, en este sentido, hablar de la particular lectura del Poder que realiza Luis Antonio de Villena en estas Imágenes en fuga de esplendor y tristeza, y que completan una suerte de trilogía foucaultiana, paralela a los libros que comentamos al inicio, de este «ciclo», y que van desde la prosa del mundo, la arqueología del saber, y ahora esta microfísica del poder sintetizada en cada una de las «imágenes», fotografías o no, virtuales o no, que analizan y detallan, con la grandeza de la poesía, algunos de estos aspectos.

Basten, por tanto, estas breves palabras para recomendar esta nueva entrega villeniana. Sus lectores le estamos agradecidos. 